\title{
When the working day is through: the end of work as identity?
}

\begin{abstract}
This article seeks to present a counter-case to the 'end of work thesis' advocated by writers such as Beck, Sennett and Bauman. It argues that work remains a significant locus of personal identity and that the depiction by these writers of endemic insecurity in the workplace is inaccurate and lacks empirical basis. The article draws upon case study data to illustrate how, across a range of workplaces, work remains an importance source of identity, meaning and social affiliation.
\end{abstract}

Keywords: flexibility/identity/insecurity/non-standard work

\section{Introduction}

The modern workplace is a locus of seemingly constant change. One interpretation of the impact of this change on workers is the 'nightmare' scenario (Fevre, 2007) propounded by a range of social theorists, who argue that work plays a much diminished role in the contemporary life experience (Bauman, 1998; Beck, 2000, 1992; Sennett, 2004, 1998). By contrast with a society based on production, ours is a 'consumer society' in which work has lost its 'privileged position as an axis around which all other efforts at selfconstitution and identity-building rotate' (Bauman, 1998: 32).

This notion of the rise of the consumer society and the concomitant demise of the 'work ethic' found in a society based on production (Bauman, 1998) is intimately bound up with the view that we have entered an 'age of insecurity' in relation to employment (Beck, 2000; Sennett, 2004). Arguments around the diminished centrality of the work experience are intertwined with a focus on the alleged instability of much contemporary work. As attention became increasingly focused on the drive by employers for greater 'flexibility', links were drawn (often assumed) between such flexibility and a seeming proliferation of inherently insecure, non-standard work (Beck, 2000). As we will see, although the parameters of what actually constitutes non-standard work have not been very clearly stated, from the starting point of the insecure workplace multifarious propositions have been forwarded about social and personal life in the 'post-industrial' age (Beck, 2002, 1992).

This research sought to investigate whether the claims of the 'end of work prophets' (Auer, 2005) stand up to empirical scrutiny. This has been questioned by numerous studies that review large-scale macro data on trends in working life (Doogan, 2005, 2001; Fevre, 2007; Green, 2006). Here, indepth case studies of employees in four Irish workplaces looked for evidence 'on the ground' to test the end of work thesis. The research explored 
employees' relationship to their work (and its role as a source of identity) and investigated issues of insecurity in contemporary working life. Qualitative and survey data are used to question the validity of the end of work thesis. The data show that work retains its importance as an essential source of intrinsic worth and value, and social affiliation. The data also show that arguments based on the alleged insecurity of modern employment are based on questionable empirical foundations.

\section{The Axis of Identity}

Beck (1992: 139) argues that in the industrial age work became the 'axis of living'. Changes in the contemporary labour market, however, have signalled the break-up of a traditionally homogenous and collective experience of employment and the labour market, through its interlinked processes of education, mobility and competition, has now become the driving force behind the individualisation of people's lives (Beck, 2002, 1992). Bauman argues that we live in a consumer age in the sense that society 'engages its members primarily in their capacity as consumers' (1998: 24 , emphasis in the original). Central to this idea is the concept of the 'work ethic'; that there is a moral dimension to work that is valued by society, as work has traditionally been seen as 'good' in and of itself. The problem, as Bauman, Beck and others see it, is that work has now lost its position as an axis around which all other attempts at identity-building rotate.

In large part this is due to the reduction in secure work discussed below, but it is also because of the demise of the work ethic; instead work is now judged by 'aesthetic criteria'. Bauman argues that, in a consumption-dominated society where the work ethic is no longer potent, jobs that are 'interesting' are the privilege of the (elite) few. For others (the rest), 'rough coercion' is required to accept jobs that offer no aesthetic satisfaction. After all:

'The flexible labour market neither offers nor permits commitment and dedication to any currently performed occupation. Getting attached to the job in hand, identifying one's place in the world with the work performed is neither very likely nor to be recommended given the short-lived nature of any employment' (Bauman, 1998: 35).

In any case, it might be argued, getting attached to the job in hand has become more difficult for contemporary employees. Gallie et al. (2004) describe the central place held in the literature on employment relationships by task discretion (the degree of initiative or control employees can exercise over their work tasks). The end of work prophets posit a view of contemporary work, based on the idea of labour market segmentation, where a dichotomy exists between (diminishing numbers of) privileged, core employees, who, as a result of technological change and higher qualification levels, experience greater task discretion, involvement and aesthetic satisfaction at work, and (increasing numbers of) peripheral, insecure employees, who experience tighter management control and 'rough coercion'. 
However, even for those fortunate core employees the experience may be one of relative coercion. This is so despite the recent discourse of 'employee involvement', 'voice' and 'partnership' at work (Boxall et al., 2006; Roche and Geary, 2006; Storey, 2005). It may be argued that employers are increasingly concerned with securing the commitment of (particularly, but not exclusively, core) employees as a means of improving work performance and organisational productivity. This may be best achieved through increasing task discretion and involving employees in the organisational decision-making processes, often through various forms of group participation (quality circles, team-working, participation in information and consultation or partnership committees; Dundon et al., 2004; Marchington et al., 2001). However, it has also been suggested that moves to increase employee involvement and voice at work can be viewed as a mechanism for strengthening organisational control (Gallie et al., 2004). Moreover, it has been argued that relative employee autonomy can exist side-by-side with increased delegation of responsibility to employees to meet the employer's market-determined economic objectives; this can lead to the emergence of '(organisation) dependent independent employees' and a model of work organisation where employee compliance and direct management control are more likely to feature (Dølvik and Waddington, 2005: 323).

The individualisation of modern life driven by changes in the labour market, the demise of the work ethic and the rise of endemic workplace insecurity have further consequences. Work has traditionally been seen as an important locus of social relations; a place for informal social interaction, for creating ties and small group solidarities with work colleagues (Felstead et al., 2005). This aspect of employment, in a consumer society, is also diminished as working life becomes increasingly atomised and fragmented.

It is, of course, possible to argue that the 'demise of the work ethic' is without foundation simply because it is based on a false assumption that people ever held such an ethic in the first place. Equally, it may be argued that work never was the 'axis of living' claimed. Nevertheless, I will argue below that, for respondents in this research at least, far from 'rough coercion' or working to survive, the work experience is of some inherent value to the individual in terms both of the work task itself and in terms of social relations at work.

\section{Insecurity and Non-Standard Work}

As indicated above, the end of work thesis tends to rest significantly on the implications of a posited increase in 'non-standard' work. The argument can be difficult to unpack, as the end of work prophets tend towards rather sweeping generalisations. For Sennet $(2004,1998)$ the personal consequences of work in the 'new capitalism' mean that there is 'no long-term' and that institutional restructuring has accompanied short-term, contract and episodic labour. Beck (2000; 1992) posits a 'risk society' in which the temporal destandardisation of labour based on part-time and temporary employment leads to the social structure of Western democracies 'coming to resemble the patchwork quilt of the south, characterised by diversity, unclarity and insecurity in people's work and life' (2000: 1). Bauman suggests that the 'work 
society' is a thing of the past and has been replaced by a society where 'permanent, well-guarded and assured jobs are now a rarity...new vacancies tend to be fixed-term, until further notice and part-time' (1998: 27). He argues that 'identifying one's place in the world with the work performed' is somewhat futile given the short-lived nature of any employment.

Three strands of the 'insecurity thesis' are addressed here. First, there is a need to clarify the parameters of 'non-standard' work. Secondly, there is a need to address the argument that forms of work that deviate from the 'standard' (which seems to equate in these accounts to full-time, permanent employment) are inherently insecure. Thirdly, the question of whether the increase in job insecurity posited has occurred at all must be considered.

For the end of work prophets, 'non-standard' work seemingly encompasses any use by employers of labour that is not regular, full-time and based on indefinite employment contracts, and refers, particularly, to part-time, fixedterm and temporary work. However, classifying workers in such a broad manner is fraught with difficulty (Felstead and Jewson, 1999). For example, Olsen and Kalleberg (2004) point out that 'temporary' workers can include those hired directly by the organisation for a fixed period, workers supplied by agencies, as well as contract company workers. Similarly, all three groups may consist of full-time or part-time workers, may vary by skills or educational background, and may enjoy long-term, or short-term employment. Such niceties of gradation rarely occur in the accounts of the end of work prophets.

Instead, as Doogan (2001) contends, there is a tendency to lump both parttime and temporary workers together in a 'peripheral' sector, as, by doing so, it can be assumed that both categories of employment are equally precarious (and thus constitute 'degraded' work). The end of work thesis seems to rest significantly on an association between an increase in non-standard work and an alleged inherent insecurity in such employment. Doogan argues that it is necessary, in particular, to re-consider the nature of part-time employment (which makes up the largest group in the category), as this employment is not necessarily impermanent or peripheral. Such 'flexible' work can be important, for example, in terms of balancing work and family, or educational, commitments (Hakim, 2000). Accordingly, differences in employees' experiences of, and orientation to, part-time work need to be appreciated (Doogan, 2005).

Fevre (2007) notes that measuring job (in)security is also problematic. In practice, measures tend to involve considerations of the numbers of employees without indefinite contracts of employment, employee selfreporting and measures of job tenure. On all of these grounds the end of work thesis has been questioned. Doogan $(2005$; 2001) cites data on long-term employment rates (those working for the same employer for more than 10 years) in Europe to argue that jobs are not becoming increasingly impermanent. He argues that increases in long-term employment can be found in both the private and public sectors and 'do not support a distinction between "traditional" and "new" industries' (2001: 428). He also found in the UK context that job tenure was increasing in both full-time, and part-time, 
work. Green (2006) argues that job insecurity actually fell during the 1990s in Britain and the US and is still greatly linked to patterns of unemployment rather than any more fundamental social change. Fevre concludes that the evidence from countries to which the end of work prophets most frequently refer (e.g. Britain and the US) does not support the idea of an age of insecurity, that evidence from other countries is patchy, and that international comparisons reveal different trends, the causes of which are most likely to be found in complex multi-factoral explanations (2007: 518). Furthermore, far from any general degrading of work, there is considerable evidence (see Felstead et al., 2002 for UK data) emphasising the prevalence of upskilling in recent years, as the overall level of qualification required for work has increased.

This research examined issues identified in these reviews of macro data by investigating the experiences of employees ('standard' and 'non-standard') 'on the ground'. In the next sections, the rationale of, and methods used in, carrying out the study are outlined.

\section{Methodology}

The empirical research on which this article is based, conducted in 20032004 , consisted of case studies of four large, unionised organisations. ${ }^{1}$ The four organisations chosen were Busco (a public sector bus company, which essentially occupies a monopoly position in the city), Urban City Council (the environment and transport divisions), People's Bank (a multinational corporate bank) and Darbstore (a multinational retail supermarket). For each, a particular case study site was chosen (a Busco garage, a Darbstore outlet, etc).

In total 58 semi-structured interviews were carried out with employees, and union and company representatives, and a questionnaire was devised and distributed to employees. The main qualitative research was carried out during day-long visits (ranging from three to five occasions) to the workplaces. At each workplace the initial visit involved interviews with the local union representative and a management and/or human resource (HR) representative. At the end of these, respondents were asked to suggest employees to be interviewed. Each interviewee, in turn, was asked to nominate other candidates ('snowballing'). Respondents were selected on the basis of making the sample as representative of the workplace population as possible, taking account of factors such as age, gender and employment status (e.g. part-time, fixed-term etc).

The interviews (recorded and transcribed) ranged in duration from around forty minutes (employee interviews) to two hours (key informant interviews with union and company representatives). In all 42 interviews were conducted with employees; 10 bus drivers, 12 retail workers, 10 financial services workers, and 10 council workers. The interviews were loosely structured around the detailed survey questionnaire. Three broad themes were explored; respondents' satisfaction with the extrinsic (e.g. pay, physical work environment) and intrinsic (e.g. interest in the work, skill levels) aspects of 
their job, including a focus on perceptions of work intensification and job security; their views of the employer organisation and local management, including their perceptions of employee voice and involvement in their organisations; and how respondents balanced their working, family and leisure time. These issues (focused around respondents' associations with work and the employer, and the relationship between work and the broader life experience) were explored in order to subject to empirical scrutiny the core theoretical propositions of the end of work prophets, and to consider the macro level data of their primary critics at the micro, workplace level.

A total of 360 survey questionnaires were distributed randomly across the workplaces with 129 responses received (a 36 percent response rate). Although randomly distributed, the survey respondents reflected well the profiles of the workplaces; for example, Busco respondents were mostly male and in their forties; retail respondents were mostly female, with a third aged under thirty. The data were analysed using both qualitative (NUD*IST) and quantitative (SPSS) software packages.

The study, therefore, is relatively small-scale, although I will draw extensively on national and international macro level data to support the localised findings. As we will see in the following section, the organisations were also strategically chosen in order to address key tenets of the end of work thesis discussed above.

\section{The Case Study Organisations}

The workplaces chosen for this research, while all unionised, reflect different types of organisation with different organisational goals and interests and different types of employees with quite different work-based concerns. The public sector workplaces demonstrate traditional 'core' public service interests and are characterised by relatively bureaucratic organisational structures and work patterns. The private sector workplaces are located in highly competitive product markets, both at the 'low end' (retail) and 'high end' (financial services).

Bus work remains a full-time, male-dominated, blue-collar occupation; by contrast, the retail workforce, while blue-collar, is largely feminised, with significant numbers of part-time and temporary workers, and relatively high employee turnover rates. Council administration work remains largely full-time and female-dominated, with relatively standardised work organisation patterns. Jobs in financial services are characterised by a relatively equal gender balance (at least at junior levels), and, traditionally, by quite standardised work organisation patterns; since the early 1990s, however, differentiated working hours, work organisation and contractual arrangements have become the norm (Regini et al., 1999).

All four workplaces are, and have been, facing ongoing and rapid change. The private sector workplaces are owned by parent multinational corporations (MNCs), and operate in fiercely competitive international product markets and in sectors that have become highly internationalised and consolidated (Bosch 
and Lehndorff, 2005). In the public sector key recent developments include moves towards deregulation, privatisation and performance benchmarking, as well as attempts to introduce 'consumerist' principles (OECD, 1995) to public service provision. At the time of the research, for example, significant discord between the state and the union movement had arisen around proposals to deregulate public transport in the local bus market, which led to the unions mounting a strong campaign against deregulation.

The workplaces are obviously characterised by sectoral, organisational and compositional specificities. Given that, we might expect to find different responses across the workplaces to the questions thrown up by the discussion above. In Bauman's terms the only employees potentially engaged in 'exciting' work here would be the financial services employees; work in retail, transport and council administration would likely fare badly in any 'aesthetic' judging process. However, given the patterns of employment in the public sector, where we would expect more 'standard' full-time and permanent employees to be found (Olsen and Kalleberg, 2004) we might expect social networks to be stronger than in sectors, especially retail, characterised by more non-standard employment patterns. It is in these latter sectors too that we would expect to see little interest (or, indeed, opportunity) for employees to get 'attached to the job in hand', as the end of work thesis presupposes that work here is likely to be 'short-lived'. In terms of job security, we would expect to find higher levels of insecurity among those employees working in the private sector, but, as the end of work thesis postulates that permanent and assured jobs will become a 'rarity', we might expect some form of insecurity to manifest across all the workplaces.

Finally, and by contrast with the 'nightmare' scenarios above, we might expect evidence of increased employee involvement and voice in all four workplaces. The literature on contemporary service sector employment (both public and private) emphasises the need for organisations to 'differentiate' themselves on the basis of 'quality service' and 'customer care' (Bosch and Lehndorff, 2005). Thus, arguably, the need to generate employee commitment grows ever more acute in such sectors; as we have seen this might best be achieved by involving employees in the organisational decision-making processes. This point is amplified in the Irish context by the participation of the Irish trade union movement in the social partnership process since 1987. This process includes a commitment to promoting partnership at enterprise level, with the discourse of enterprise partnership being framed in terms of solidarity, inclusiveness, participation and workplace democracy (Roche and Geary, 2006). ${ }^{2}$

\section{It Ain't What You Do, It's the Way That You Do It}

This section addresses the argument that work no longer generates the inherent value that accompanied the work ethic, but has instead been reduced to an 'aesthetic scrutiny'. Respondents were questioned on levels of satisfaction with different aspects of their job, both extrinsic and intrinsic. The majority of respondents worked in what might be considered relatively 
monotonous, controlled and routine jobs. However, the employees themselves had a very different view.

Across all four workplaces, employees reported relatively high levels of task satisfaction. ${ }^{3}$ Among bus drivers, several reasons were advanced for this, key among them being the intrinsic satisfaction in driving for a living and the social interaction with passengers: 'Well, I love driving. And I'm a people person too' (Lorna). Perhaps most surprisingly, a clear majority of interview and survey respondents (52 percent of survey respondents) working in retail (strongly/) agreed that their work was interesting (only 26 percent disagreed/strongly disagreed). Again, this was often due to the social nature of the work (interaction with customers) and the diverse range of tasks:

'No two days are the same. You meet different people every single day of the week. Everybody has different things going on in their lives and nine times out of ten customers coming in will tell you' (Nick).

In addition to finding work interesting, in three of the four workplaces, approximately two-thirds of respondents reported they had a 'good opportunity to learn new skills at work'. ${ }^{4}$ What is noteworthy is that in all workplaces respondents were either satisfied that they could increase their skill levels or were actively seeking to do so; this would seem to demonstrate at least some level of commitment to 'getting attached to the job in hand'.

Interestingly, between 70 and 87 percent of survey respondents across the workplaces reported that they worked free from unnecessary management interference. This, in the context of what we might think of as quite routinised and controlled work, seems somewhat counter-intuitive, but is strongly supported by the interview data. Across the four workplaces, what respondents constantly cited as attractive in their job was the level of autonomy they had. This might be expected amongst the more high-skilled financial services respondents, but it was a factor cited also by retail 'shelfstackers' and council clerical workers. One council worker described that what she liked about her work is that: 'you're in your own little world and nobody bothers you...you're in control of it' (Noelle). Similarly, several of the retail workers focused on the autonomous nature of their work as a positive. Carla described how she felt moving back to stacking shelves was liberating:

'Two or three years ago I was checkout supervisor, which was to me very stressful, because they won't give you any staff. So where I am now I'm just left alone packing shelves and I'm happier'.

What is significant is the manner in which what might be objectively described as routine, monotonous and controlled work is seen as otherwise by the workers themselves. This would seem to suggest that work does (still) satisfy some intrinsic needs traditionally associated with a 'work ethic' (achievement, fulfilment, a sense of worth or duty). Equally, employees across the four workplaces were quite consistent in their responses; in all workplaces levels of task satisfaction, and satisfaction with both levels of autonomy and with 
upskilling opportunities (with the proviso mentioned in relation to bus drivers) were relatively high and strikingly uniform.

\section{'People. I Love People. Old, Young, Lovely People' (Fiona).}

Another element of the work experience this research explored was that of social networks/relations. For respondents across the workplaces, but particularly those in retail and transport who worked on the 'the front line', the social nature of the task itself was key to their enjoyment of work. The second most cited reason for working in retail (after the flexible nature of the job) was social contact with customers. A typical quote was:

'The job l'm doing now (customer service) is mostly pluses because I like dealing with people and I like arguing! I love the job I'm doing now' (Deirdre).

A second aspect of social relations at work concerned relationships with colleagues. The importance of this element of the working experience is highlighted in the European Foundation survey, where the most important factor (along with pay) correlated with general satisfaction with working conditions is a sense of 'social integration' in the organisation (European Foundation, 2006: 79). A series of survey questions was asked about this area of working life.

In each workplace, more than a third of respondents socialised informally with colleagues 'at least once a month', with another third socialising 'less than once a month'. Approximately a third of retail and bus workers 'never' socialised informally with colleagues, while just 6 percent of council workers and 17 percent of financial services workers gave this as their response. The numbers of those participating in organised social events (e.g. BBQs etc.) and work clubs/societies were lower. In the case of the former, almost half of retail and bus workers 'never' attended such events; in Urban Council and People's Bank the majority were likely to do so 'less than once a month'. In terms of clubs/societies, in Busco 25 percent were likely to participate 'at least once a month' but around half 'never' participated. For the two white-collar workplaces only around 16 percent participated at 'least once a month' and in Darbstore three-quarters 'never' participated.

These figures, however, depend significantly on the opportunities to socialise and the facilities available. For example, the employee social club in Darbstore had recently been disbanded due mainly to a withdrawal of company subsidies. Nevertheless, social networks with colleagues were cited as important by the majority of the Darbstore interview respondents:

'We have a Darbstore "group". Last week we went out and there was about fifteen of us from Darbstore and that used to work in Darbstore' (Bianca). 
Several financial services respondents emphasised that they still valued relationships with colleagues in other branches of People's Bank (where they had previously worked) and, indeed, with colleagues in other financial services organisations. This echoes a point made by O' Carroll (2003) in her study of workers in the Irish software industry. She concluded that social networks were not necessarily related only to occupation but more broadly defined as being part of an industry, so that job mobility can result in the creation of bonds, which exist between organisations and are not dependent for their survival on the space, place and time of the organisation.

The point here is that work continues to provide an opportunity to socialise with people outside of the family and, even though not all workers will choose to avail of this, ${ }^{5}$ virtually all work involves some interaction with others (be they managers, colleagues, subordinates, clients, or the public). Complex social systems develop within the workplace that often spill over into leisure time, providing a link between the work and leisure spheres (Noon and Blyton, 2002).

\section{Non-Standard Work and Instability}

As anticipated, the prevalence of non-standard work arrangements varied according to workplace. Busco employees were almost exclusively full-time and permanent. This was the case also in the council (although two interview respondents had moved from a fixed-term to a permanent contract and one 'job-shared'). Approximately a fifth of People's Bank employees had part-time contracts (two interview respondents there had also moved from a fixed-term to a permanent contract). Non-standard employment arrangements were most prevalent in Darbstore, where approximately half of employees worked parttime. A further 20 percent were full-time and permanent, with the remainder working on temporary (often seasonal) contracts. ${ }^{6}$

Contrary to the expectations of the end of work prophets, none of the parttime respondents in the retail sector professed themselves dissatisfied with their status. This type of non-standard working was convenient for them in order to fulfil domestic responsibilities or to facilitate educational pursuits. Bianca illustrates this point well:

'I'm part-time; normally 5 to 10 in the evenings, Wednesdays, Saturdays and Sundays. They adjust your hours for whenever you want. Like, I can't work Thursdays (because of college commitments) so l've never worked a Thursday since I started'.

A female council respondent similarly cited the availability of job-sharing as the key attraction of the job. Furthermore, those council and financial services interview respondents who had started work on fixed-term contracts had subsequently been made permanent. The findings here seem to be in line with Irish and international evidence. The European Foundation survey (2006) found that almost 60 percent of all part-time workers were satisfied with their hours, with just 15 percent saying they would prefer to work more hours. Furthermore, O' Connell et al. (2004) found that those working part-time 
expressed higher levels of job satisfaction than those working full-time. A range of international evidence also suggests that temporary employment is often used to recruit for permanent positions (OECD, 2002), underscoring the dependence of the nature and quality of non-standard work arrangements on the institutional context (Olsen and Kalleberg, 2004).

That is not to ignore the potential negative consequences for employees of an increase in non-standard work. The point has already been made that a feature of the literature is to lump together different types of such work practices and label them 'non-standard'. Respondents here cited the benefits of being able to engage in part-time work, in particular. However, a specific issue raised by retail respondents was the use by Darbstore of so-called 'flexible' contracts. Many temporary, and some part-time, employees have 'on-call' contracts of 18-30 hours per week. This means those employees' hours are reduced if the company feels the need to lower costs. The potential costs to employees of this type of work were vividly portrayed. These were both financial (being unable to demonstrate a fixed income while seeking a loan, for example) and personal; one respondent who had moved from a flexible to a permanent contract (with guaranteed hours) described the situation that pertained before the shift:

'You couldn't plan anything. If you met friends the night before you could never say, "right, l'll be there." You just couldn't ever be sure' (Nick).

The intention here is not to cast doubt (quite the contrary) on the fact that important changes in employment structure described by Bauman, Beck, Sennett and others continue to take place. However, the data here question the notions, first, that such changes (and, in particular, the increase in parttime employment) should be associated automatically (as it often seems to be in those authors' work) with inherently unstable employment and 'bad jobs'.7 Indeed, as Auer (2005) points out, stable jobs are not always equivalent to 'good jobs' but can be involuntary and/or undesirable (e.g. people locked into their jobs without being able to change).

Secondly, and following on from that, the data question the idea that the spread of such employment practices should be used to demonstrate a decline in the significance of work as 'the flexible labour market neither offers nor permits commitment and dedication to any currently performed occupation' (Bauman, 1998: 35). One female retail respondent gave up work after giving birth, but now (with two pre-teen children) had chosen to work part-time in Darbstore because 'I felt that I was missing out on something. I'm glad I'm back. I enjoy the stimulation' (Joan).

In terms of the younger retail respondents, working part-time facilitated school and college attendance. Interestingly, despite the eldest of this group being just 24, all had worked at Darbstore for at least three years. The youngest respondent (aged 17) had been working there for three years and intended to remain working at Darbstore while he completed his college course. Thus, while the younger respondents at this stage in their lives undoubtedly viewed 
their jobs at Darbstore as 'stepping stones', the likelihood is that all will have spent a not inconsiderable portion of their working lives with the company (and, as outlined above, there are attractions to employees in terms of intrinsic satisfaction gained from the job and the social bonds formed at the workplace). These respondents may not define themselves as 'retail workers'; this does not necessarily imply a lack of commitment either to retail work or their employer, at least for the period they are employed in the sector. ${ }^{8}$ It is not readily apparent why commitment to the job or the employer should necessarily be conflated with a 'job for life'.

\section{The Insecurity Thesis and 'Manufactured Uncertainty'}

Let us turn then to the related question of job (in)security. In this research, a clear majority of respondents across all four workplaces professed themselves satisfied with their security of employment. However, just under 30 percent of respondents in the financial services, retail and public transport sectors reported they were not satisfied. ${ }^{9}$ In the interviews very few respondents raised the issue of job insecurity. Where it did come up, it was generally raised by respondents in relation to other people or in a rather nonspecific way: 'well, obviously l'm lucky to have a permanent job with the way things are at the moment' (Jill). This quote (from an employee in one of the fastest growing sectors of a full employment economy) illustrates the point that even when people are confident about keeping their job, they can still worry about the prospect of losing it.

To explain the paradox between people's perception of insecurity and the actual probability of losing their jobs Doogan (2001: 436) develops the idea of 'manufactured uncertainty' and proposes that job insecurity which relates to specific individuals is replaced by economic insecurity to reflect the wider social sense of uncertainty in the contemporary economic, political and institutional environment. It would seem that a significant factor causing distress to employees in both Busco and Darbstore was the 'manufactured uncertainty' that accompanies the increasing exposure of employees to market forces, in this case the proposed deregulation or, as many respondents saw it, privatisation of public transport and the experience of acquisition (takeover) of a domestic company by a large, foreign multinational in Darbstore. ${ }^{10}$ This was summed up by a quote from a Busco union workplace representative:

'One of the biggest difficulties in bus work is that drivers feel disconnected or disempowered about the fact that decisions are made over and above and about them without them having any input'.

In Darbstore several of the longer-term staff made reference to the decline in staff-management relations since the company had changed ownership, all emphasising the feelings that accompanied being part of a large, global corporation: 'to Darbstore you're just a number and that's as far as it goes' (Orla). Some respondents were extremely clear that their ire was directed at the company rather than immediate management: '(the company) are 
miserable...it doesn't really apply to managers. They're all just clones anyway' (Fiona).

What quickly became apparent from the interview data was that very few respondents focused on the likelihood of losing their own job; rather that they were articulating a prevailing or received wisdom about the 'state of things'. Where this originated from is open to question, but it is arguable that employers may have some interest in maintaining concerns about the security of employment. ${ }^{11}$ However, it was certainly the case that respondents in all of the workplaces were frustrated by their organisations' failure to communicate effectively with them about their work and the direction of the organisation. Across the four workplaces, around three-quarters of survey respondents reported their organisation did not 'keep staff well informed'. Busco was in a particular situation where the future of the company was the subject of intense debate amongst the work force (and indeed the general public). Many respondents complained that, although their futures were at stake, they were being kept to a large extent in the dark: 'there's a lot of uncertainly in the company. People don't know what's happening' (Frank).

Again, this reflects the national picture. O' Connell et al. (2004) found that approximately one quarter of respondents reported that they were 'rarely' or 'almost never' consulted prior to major decisions, provided with feedback on why decisions had been made or, even where prior consultation had taken place, had any attention paid to their views. In this research, respondents' perception of a lack of employee voice led to a feeling of insignificance (particularly in the case of those working for large MNCs) and a loss of control as decisions were made 'above and about them'. Consequently, insecurity, although in most cases of a vague and ill-defined sort, remained an issue for a significant portion of these respondents. In none of the four workplaces (even amongst the higher-skilled financial services employees) was there evidence that the anticipated increase in employee involvement and voice had occurred. This was the case even though various forms of 'involvement' mechanisms were identified; partnership committees in the council, teamworking in People's Bank, attempts, through direct communication, to extend Busco's 'cultural umbrella' (Busco HR representative), and a 360 degree feedback process and regular in-store briefing newsletters in Darbstore. I will reflect briefly on this in the concluding section.

\section{Conclusion}

The findings of this research can be summed up quite succinctly: work matters. Significantly, the data do not show any significant difference in terms of the importance of work to these respondents that corresponds with a particular workplace or group of employees. Given the very different nature of the workforces and organisations here this is surprising. Beck (2002) argues that in our 'individualised' society contemporary social relations are subject to high risk and face high levels of uncertainty. However, this research suggests that work does still fulfil for people important personal and social needs and that the workplace remains an important locus of social relations. Many of the arguments from the end of work prophets seem to rest on the implications of a 
'destandardisation of labour' (Beck, 1992: 139). This is best summed up by Sennett's phrase 'no long-term'; the view that work has become short-term, contract-based and episodic. The evidence presented here, however, strongly supports those that question this view (Auer, 2005; Doogan, 2005; Francis, 2006).

What provoked most discontent among all groups of employees, however, was the feeling that they were not kept adequately informed about issues that affected their working lives; that they had insufficient say or voice at work. This was so despite the fact that in each workplace some forms of 'new' employee involvement mechanisms were to be found. A comprehensive assessment of how these operated and why employees perceived them to be inadequate in securing greater employee voice is beyond the scope of this article. However, it is interesting to note that while most respondents felt disconnected from the organisation and managerial decision-making, many cited autonomy in their own work as one of the attractive features of their jobs. This may support the idea that devolving relative autonomy to employees, through, for example, partnership committees or team-working structures, is not incompatible with (increased?) management control (Gallie et al., 2004). Moreover, it may be that such a seeming contradiction reflects a sense of appreciation amongst employees of being away from the stress of tough decisions (concentrating instead on the immediate, personalised task in hand) in an apparently more uncertain macro environment.

I argued that this lack of voice contributed significantly to an uncertainty that was 'manufactured'. A criticism of Doogan's concept might be that the very factors suggested as contributing to 'manufactured uncertainty' (the marketisation of public services, the increased exposure of employees to direct market forces) are not all that different from those suggested by the end of work prophets to back up the insecurity thesis. The distinction, however, lies in the view of the consequences of these issues and in the possible responses of employees to them.

This leads on to a consideration of the implications of these findings for collective workplace representation. For the end of work prophets, the future for trade unionism is one of irrelevance. At a macro level developments continue to occur that seem to close off the space for collectivism in the modern workplace as they lead to (indeed precipitate) a breakdown in solidarities and the atomisation and fragmentation of (working/) life. However, the findings here suggest that this is simply not the case. For example, the Busco respondents were in the 'front line' in facing the threat of deregulation, but had chosen to resist perceived attempts to downgrade their working conditions through collective action. ${ }^{12}$ For the respondents here, these macro processes were not seen as inevitabilities, but as legitimate subjects for (collective) negotiation. For the end of work prophets, the rise of the consumption society and decline in importance of work have all sorts of implications for wider social arrangements including: 'social classes, familial forms, gender status, marriage, (and) parenthood' (Beck, 1992: 87). The evidence here suggests the need for more careful empirical testing of such claims. 
As regards 'non-standard' work, it is true that collective interest definition may have become more complex. However, while heterogeneity in the individual employee's terms and conditions challenges a 'command and control' form of collectivism based on mechanical solidarity (Hyman, 2001), it is surely too extreme to conclude that space for other conceptions of solidarity is largely eliminated (see Wills and Simms, 2004, for example, on the potential of 'community unionism'). Indeed, it seems logical to speculate that the changes in the contemporary world of work (more temporal flexibility or more variegated remuneration structures, for example) will throw up new and complex work-based concerns in respect of which employees may seek collective representation. This is an empirical question with which those who see collectivism as an anachronism in contemporary working life rarely engage.

\section{References}

Allan, C., Bamber, G. and Timo, N. (2006) 'Fast-food Work: Are McJobs Satisfying?', Employee Relations 28 (5): 402-420.

Auer, P. (2005) Protected Mobility for Employment and Decent Work: Labour Market Security in a Globalised World. Employment Strategy Paper No. 5. Geneva: ILO.

Bauman, Z. (1998) Work, Consumerism and the New Poor. Buckingham: Open University Press.

Beck, U. (2002) Individualisation: Institutionalised Individualism and its Social and Political Consequences. London: Sage.

Beck, U. (2000) The Brave New World of Work. Cambridge: Polity.

Beck, U. (1992) Risk Society: Towards a New Modernity. Cambridge: Polity.

Bosch, G. and Lehndorff, S. (2005) Working in the Service Sector: A Tale From Different Worlds. London: Routledge.

Boxall, P., Haynes, P. and Freeman, R. (2006) Employee Voice in the AngloAmerican World. Ithaca: Cornell University Press.

Dølvik, J.E. and Waddington, J. (2005) 'Can Trade Unions Meet the Challenge? Unionisation in Marketised Services' in G. Bosch and S. Lehndorff (eds) Working in the Service Sector: A Tale From Different Worlds. London: Routledge.

Doogan, K. (2005) 'Long-Term Employment and the Restructuring of the Labour Market in Europe', Time and Society 14 (1): 65-87.

Doogan, K. (2001) 'Insecurity and Long-term Unemployment', Work, Employment and Society 15 (3): 419-441. 
Dundon, T., Wilkinson, A., Marchington, M. and Ackers, P. (2004) 'The Meanings and Purpose of Employee Voice', International Journal of Human Resource Management 15 (6): 1150-1171.

European Foundation for the Improvement of Living and Working Conditions. (2006) Fourth European Working Conditions Survey. Luxembourg: Office for Official Publications of the EC.

Fevre, R. (2007) 'Employment Insecurity and Social Theory: The Power of Nightmares', Work, Employment and Society 21 (3): 517-535.

Felstead, A., Jewson, N. and Walters, S. (2005) Changing Places of Work. Basingstoke: Palgrave.

Felstead, A., Gallie, D. and Green, F. (2002) Work Skills in Britain 1986-2001. Nottingham: DfES.

Felstead, A. and Jewson, N. (1999) Global Trends in Flexible Labour. London: Macmillan.

Gallie, D., Felstead, A. and Green, F. (2004) 'Changing Patterns of Task Discretion in Britain', Work, Employment and Society 18 (2): 243-266.

Green, F. (2006) Demanding Work: The Paradox of Job Quality in an Affluent Economy. Princeton: Princeton University Press.

Hakim, C. (2000) Work-lifestyle Choices in the 21st Century: Preference Theory. Oxford: Oxford University Press.

Hyman, R. (2001) Understanding European Trade Unionism. London: Sage.

Marchington, M., Wilkinson, A., Ackers, P. and Dundon, T. (2001) Management Choice and Employee Voice. London: CIPD Publishing.

Noon, M. and Blyton, P. (2002) The Realities of Work. Basingstoke: Palgrave.

O' Carroll, A. (2003) In the Shadow of the Clock: Working Time in the Irish Software Sector. Unpublished PhD Thesis, Trinity College Dublin.

O' Connell, P.J., Russell, H., Williams, J. and Blackwell, S. (2004) The Changing Workplace: A Survey of Employees' Views and Experiences. Dublin: ESRI/NCPP.

OECD. (2002). 'Taking the Measure of Temporary Employment' in Employment Outlook. Paris: OECD. 
OECD. (1995) Governance in Transition: Public Management Reforms in OCED Countries. Paris: OECD.

Olsen, K. and Kalleberg, A. (2004) 'Non-Standard Work in Two Different Employment Regimes: Norway and the United States', Work, Employment and Society 18 (2): 321-348.

Regini, M., Kitay, J. and Baethge, M. (1999) From Tellers to Sellers: Changing Employment Relations in Banks. London: The MIT Press.

Roche, W.K. and Geary, J.F. (2006) Partnership at Work: The Quest for Radical Organisational Change. London: Routeledge.

Sennett, R. (2004) Respect: The Formation of Character in an Age of Inequality. London: Penguin.

Sennett, R. (1998) The Corrosion of Character. The Personal Consequences of Work in the New Capitalism. New York: W.W. Norton \& Company Ltd.

Storey, J. (2005) Adding Value Through Information and Consultation. Basingstoke: Palgrave.

Wills, J. and Simms, M. (2004) 'Building Reciprocal Community Unionism in the UK', Capital and Class 82 (2): 59-84.

\footnotetext{
${ }^{1}$ As with any case study research, issues of generalisability arise. In particular, all four organisations are unionised and support basic trade union institutions. In Busco and Darbstore union membership is a condition of employment. Approximately 90 percent of council employees and 66 percent of bank employees are union members. The 'union presence' therefore may affect employee orientations to work (Gallie et al., 2004), so that the attitudes reported may not be reproduced in non-unionised workplaces.

${ }^{2}$ This research was completed before the transposition into Irish law of the Information and Consultation Directive (Directive 2002/14/EC), the aim of which is to guarantee statutory rights to employee voice and involvement (see Author A, 2008, forthcoming).). The impending law was, however, mentioned as being 'on the horizon' by company representatives in all workplaces.

${ }^{3}$ In each of the workplaces, less than a third of respondents (strongly/) disagreed that their work was interesting. The European Foundation survey reports that around 80 percent of employees feel they are 'doing useful work' and that their job gives them the feeling of 'work well done' (European Foundation, 2006). Irish national data recently reported that 86 percent (strongly/) agreed that their work was interesting (O' Connell et al., 2004).

${ }^{4}$ Bus drivers were, unsurprisingly given the nature of the work, the exception; however, even here the company had recently agreed to sponsor drivers seeking Institute of Advanced Motors accreditation.

${ }^{5}$ The data did not conform to the expectation that social interaction would play a more significant role in the public sector workplaces, where patterns of work (particularly working time) are more standardised. The data suggest other organisation-specific factors (especially the location of the workplace and the availability of sport and social facilities) were more significant.

${ }^{6}$ In terms of working hours, shift-work was common in Busco (although standardised in the sense driver shifts did not usually vary from week to week) and Darbstore (where shift patterns were more variable). Council employees worked ' 9 to 5 ' patterns, while financial
} 
services employees officially worked ' 9 to 6 ' patterns, but frequently stayed late or worked weekends (unpaid).

${ }^{7}$ Absent from these authors' work generally is any consideration of the array of EU-mandated employment legislation that seeks to safeguard the rights of, inter alia, part-time and fixedterm workers.

${ }^{8}$ There was some evidence in Darbstore to suggest that training opportunities were an attractive feature of the job for less well-educated young employees; Allan et al. (2006) report similar responses in their research on Australian fast-food employees.

9 Just 3 percent of council workers reported dissatisfaction.

${ }^{10}$ People's Bank was, in fact, also acquired by a foreign MNC within 12 months of the research being completed.

${ }^{11}$ The following quotes are taken from www.ibec.ie, the website of the Irish Business and Employers Confederation (IBEC): 'IBEC says pay pause needed to save jobs' (IBEC press release 31/10/2002); 'Pay talks resume. Jobs the issue' (IBEC press release 02/06/2004); 'Employment growth figures mask worrying economic signs' (IBEC press release 14/09/2005). From 2002 to 2005 economic growth in Ireland exceeded 5 percent per annum. The unemployment rate during the period remained below 4.5 percent.

${ }^{12}$ The union stopped short of full strike action but various other types of action were taken (e.g., a 'no fares' day). The proposed deregulation has not occurred. 